WMJ (Warmadewa Medical Journal), Vol. 1 No. 2 November 2016, Hal. $42-50$

\title{
Goiter Sebagai Faktor Predisposisi Karsinoma Tiroid
}

\author{
Ni Wayan Armerinayanti \\ Bagian Patologi Anatomi Fakultas Kedokteran dan Ilmu Kesehatan Universitas Warmadewa, \\ Email: armerinayantipranata@gmail.com
}

\begin{abstract}
Abstrak
Goiter merupakan pembesaran kelenjar tiroid yang dapat berkaitan dengan gangguan primer pada organ tiroid ataupun akibat stimulasi hormonal atau faktor lain terhadap tiroid. Di Indonesia dan di Bali khususnya kasus karsinoma tiroid mengalami peningkatan sejalan dengan peningkatan kasus goiter endemik maupun non endemik. Goiter memiliki faktor risiko sebesar 2,5 kali lipat untuk menimbulkan karsinoma tiroid. Goiter dapat menimbulkan hiperplasia yang bersifat difusa maupun noduler (nodul tunggal dan multipel). Analisis klonal telah membuktikan bahwa hiperplasia merupakan proliferasi yang bersifat poliklonal. Pada tiroid, ditemukan perubahan pola monoklonal pada kelompok nodul yang sebelumnya merupakan nodul hiperplastik. Perubahan poliklonal menjadi monoklonal ini merupakan interaksi antara adanya lesi hiperplastik sebelumnya dengan predisposisi genetik yang selanjutnya menciptakan lingkungan mutagenik, ditandai oleh peningkatan proliferasi sel disertai pembentukan radikal bebas yang memicu adanya mutasi somatiktirosit. Pemberian suplementasi iodium pada kasus goiter endemik, dikatakan berkaitan dengan adanya kandungan iodine radioaktif nantinya justru menimbulkan kerusakan rantai DNA melalui tata ulang RET-TRK.
\end{abstract}

Kata Kunci: goiter, predisposisi, karsinoma tiroid.

\section{Abstract \\ [Goitre as Predisposing Factor of Thyroid Carcinomas].}

Goitre is an enlargement of thyroid gland which can be associated with primary thyroid disorders or stimulation of the gland by hormones and other factors. In Indonesia and especially in Bali, increase of Thyroid Carcinoma cases had been associated with either endemic or non endemic goiter. Goitre increases 2.5 fold risk of thyroid carcinoma. Goitre may cause diffuse and nodular hyperplasia (either single or multiple nodules). Clonal analysis has been discovered that hyperplasia is considered to be polyclonal proliferation. Monoclonal alterations had also been found in a subset of thyroid nodules that were previously considered hyperplastic. Alterations of polyclonal to monoclonal pattern was considered as interaction between past history of hyperplastic lesion and genetic predisposition which furthermore forming mutagenic environment such as increases of cell proliferation and also free radicals induce-somatic mutation. Iodine supplementation on endemic goiter related with radioactive iodine content which damaging DNA sequences in the form of RETTRK rearrangement.

Keywords: goitre, predispose, thyroid carcinoma.

\section{PENDAHULUAN}

Goiter atau struma atau secara awam dikenal dengan istilah gondok merupakan pembesaran kelenjar tiroid yang dapat berkaitan dengan gangguan primer pada organ tiroid ataupun akibat stimulasi hormonal atau faktor lain terhadap tiroid. ${ }^{[1]}$ Berdasarkan ukuran kelenjar tiroid, definisi goiter ditetapkan pada individu dengan berat kelenjar tiroid melebihi $18 \mathrm{~mL}$ pada perempuan atau melebihi $25 \mathrm{~mL}$ pada lakilaki. ${ }^{[2,3]}$ Sekitar $27 \%$ dari keseluruhan pasien goiter di dunia berada di Negara Asia Tenggara termasuk Indonesia. ${ }^{[4]}$

Di Indonesia dan di Bali khususnya kasus karsinoma tiroid mengalami 
peningkatan sejalan dengan peningkatan kasus goiter endemik maupun non endemi ${ }^{[5]}$. Berdasarkan data yang dikumpulkan dari registrasi kasus di instalasi Patologi RSUP Sanglah pada tahun 2014, sekitar 30\% karsinoma tiroid berkembang dari goiter. Hal ini menunjukkan bahwa goiter merupakan faktor predisposisi terjadinya karsinoma tiroid dan bahkan kemungkinan dapat mempengaruhi perangai biologis karsinoma tiroid..$^{[1,3,4]}$

Goiter terjadi melalui proses hiperplastik dan involusi yang berulang dan dalam setiap proses ini akan memberi peluang berkembangnya suatu perubahan yang bersifat neoplastik. Goiter memiliki faktor risiko sebesar 2,5 kali lipat untuk menimbulkan karsinoma tiroid. Penelitian sebelumnya menemukan bahwa insiden keganasan pada goiter multinoduler berkisar $7,5 \%$ hingga $13 \%$. Tidak dijumpai perbedaan yang bermakna secara statistik untuk insiden karsinoma tiroid antara pasien dengan goiter nodul soliter dan goiter multinoduler. Kasus karsinoma tiroid tersering yang terjadi pada penderita goiter adalah karsinoma tiroid papiler (KTP), yaitu sebanyak $75 \%$ kasus, sisanya sebanyak 12 , $5 \%$ adalah karsinoma tiroid folikuler (KTF). $[1,6]$

Meskipun melalui analisis klonal diketahui bahwa hiperplasia pada goiter digolongkan sebagai proliferasi yang bersifat poliklonal, sedangkan neoplasia merupakan proliferasi monoklonal tetapi ditemukan juga bahwa terdapat perubahan pola monoklonal pada beberapa kelompok nodul yang sebelumnya merupakan nodulhiperplastik dari kasus goiter. ${ }^{[1,7]}$ Mekanisme bagaimana perubahan poliklonal menjadi monoklonal ini merupakan interaksi antara faktor risiko goiter dan adanya predisposisi genetik yang selanjutnya menciptakan lingkungan mutagenik yang ditandai oleh peningkatan proliferasi sel disertai pembentukan radikal bebas yang memicu adanya mutasi somatiktirosit. Klonal tumor akhirnya terbentuk jika defek genetik tidak dapat diperbaiki. Hal inilah yang selanjutnya menjadi pencetus proliferasi sel yang bersifat neoplastik pada nodul. ${ }^{[1,2]}$ Sehingga sangat penting dalam pemeriksaan histopatologi untuk setiap kasus goiter diberikan jawaban yang lengkap mengenai adanya fokus proliferatif maupun atipikal yang nantinya berpeluang besar menimbulkan karsinoma tiroid. Informasi ini juga berguna bagi para klinisi dalam penentuan monitoring maupun terapi lanjutan terhadap pasien. Melalui tulisan ini akan dijabarkan mengenai patogenesis terjadinya goiter dan korelasinya dengan kasus karsinoma tiroid.

\section{TINJAUAN PUSTAKA}

\section{Anatomi dan Fisiologi Kelenjar Tiroid}

Tiroid merupakan kelenjar endokrin terbesar pada orang dewasa, normalnya memiliki berat sekitar 20 gram. Dimensi masing-masing lobus bervariasi dengan panjang sekitar 4-7 cm, lebar 2,5 cm dan ketebalan sekitar $1,75 \mathrm{~cm}$. Isthmus menghubungkan kedua lobus berbentuk bulat dengan luas permukaan sekitar $2 \mathrm{~cm}^{2}$ dan ketebalan antara 0,2 sampai $0,6 \mathrm{~cm}$. Kelenjar diliputi oleh kapselfibrosa yang memasuki parenkim membentuk septa yang secara regular memisahkan lobulus tiroid. Setiap lobulus ini mengandung 20-40 unit sekresi yang disebut dengan folikel (vesikel, asini atau alveoli). Folikel berbentuk bulat dilapisi oleh epitel sekretori dan mengandung koloid pada lumennya, berdiameter sekitar $0,3 \mathrm{~mm}$ atau $0,163 \mathrm{~mm}$ setelah maserasi dengan asam hidroklorik. $[7,8]$

Beberapa penelitian menemukan bahwa kelenjar yang mengalami hipertrofi secara jelas menunjukkan diameter folikel aktif berukuran antara setengah atau satu sepertiga diameter folikel yang tidak aktif. Folikel-folikel tersebut dikelilingi oleh jaringan ikat longgar yang mengandung pembuluh darah dan serabut saraf. Masingmasing lobus memiliki arteriolnya sendiri dan berakhir dengan jaringan kaliper yang mengelilingi folikel. Studi khusus yang dilakukan Model mengenai pembuluh darah ini menunjukkan bahwa terdapat anastomosisarteriovena yang memungkinkan kontrol kapiler dalam menangkap 
hormon tiroid. Terdapat empat arteri yang membawa 5 liter darah melalui tiroid setiap jam, sehingga tiroid merupakan salah satu organ yang menerima darah terbanyak setelah paru dan ginjal yaitu $4 \mathrm{ml}$ per menit per gram jaringan. Arteri tersebut tidak berpenetrasi ke dalam parenkim tiroid namun segera bercabang pada permukaan kelenjar membentuk jaringan arteriol. Hal ini menyebabkan organ tiroid untuk rentan mengalami perdarahan. ${ }^{[7,8]}$

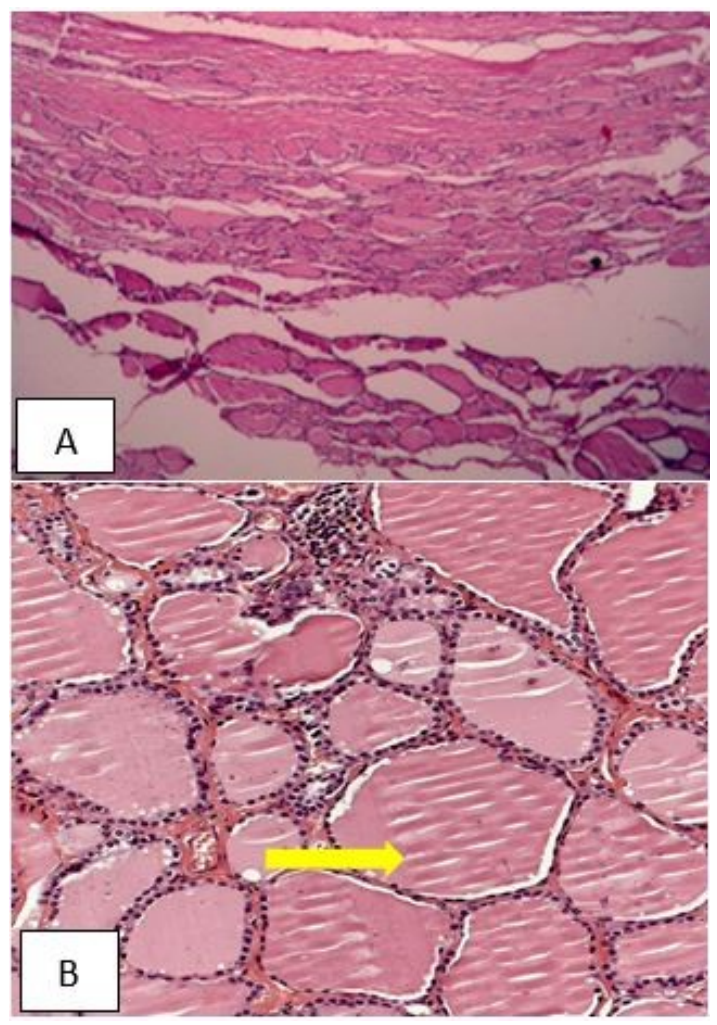

Gambar 1. A Lobulus kelenjar tiroid yang dipisahkan stroma fibrosa tipis. B. Folikel tiroid dilapisi selapisepitel kuboid dengan lumen berisi bahan koloid (tanda panah) yang mengandung prohormon tiroid.

Epitel folikel tiroid normalnya berbentuk kuboid, reguler dengan ketebalan 15 mikron dan ukurannya memanjang jika terjadi peningkatan aktivitas. Sel-sel ini tersusun dalam orientasi yang sama dan menghasilkan substansi koloid ke dalam lumen. Koloid sangat eosinofilik pada orang dewasa namun pada usia tua menjadi basofilik karena peningkatan nukleoprotein. Koloid ini dicerna oleh berbagai enzim mencakup amilase. Beberapa elemen intraseluler sel folikel tiroid berkaitan dengan aktivitas selulernya, seperti pada kelenjar yang hiperaktif maka mitokondrianya mengalami hipertrofi sehingga terjadi peningkatan area permukaan intraseluler dan peningkatan akumulasi lipid sitoplasma maupun permeabilitas membran sel. Demikian pula halnya yang terjadi pada apparatus golgi maupun struktur sitoplasma lainnya. ${ }^{[8,9]}$

Kelenjar tiroid menghasilkan hormon tiroid, namun hal ini sangat tergantung pada cadangan prohormontiroglobulin dalam koloid. Sel-sel epitel folikel tiroid memiliki kemampuan dalam mengendapkan ion yodium (iodida) dari darah dan mensintesis hormon tiroksin dan triiodotironin. Sintesis dan sekresi hormon tiroid melibatkan 2 fase yaitu fase eksokrin dan fase endokrin, keduanya diatur oleh TSH melalui mekanisme receptor binding cAMP (cyclic adenosine monophosphate). ${ }^{[8,10]}$

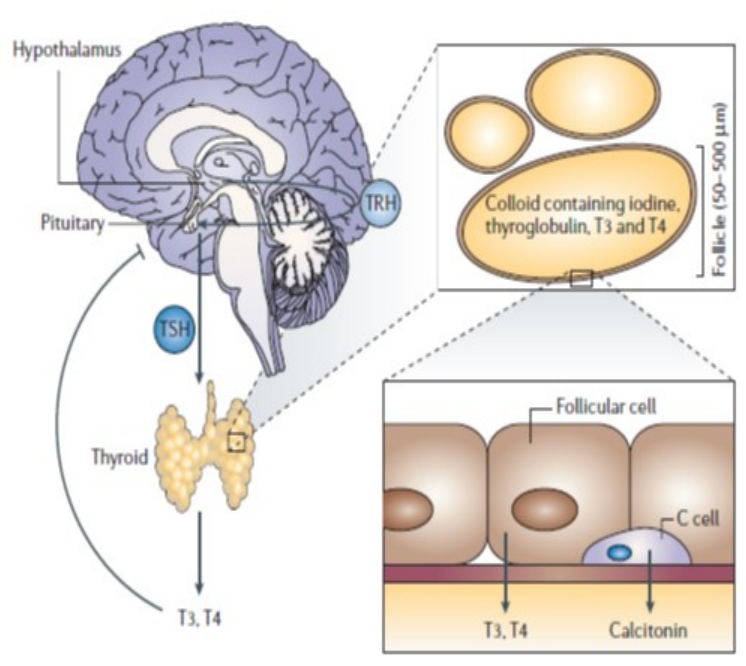

Gambar 2. Sintesis hormon tiroid melibatkan aksis hipotalamus (pelepasan TRH)-Hipofisis/Pituitari (pelepasan TSH).

(Gambar ini diambil oleh Kondo, Ezzat dan Asa, 2006 dari REF. 226 C (1996) Appleton \& Lange)

Fase eksokrin meliputi: penangkapan iodida dari darah, sintesis tiroglobulin dan penyatuan iodida dalam residu tirosiltiroglobulin oleh peroksidase tiroid. Sintesis tiroglobulin terjadi pada retikulum endoplasma kasar dan apparatus golgi. 
Tiroglubulin dikemas dalam vesikel sekresi dan dilepaskan melalui eksositosis ke dalam lumen yang mengandung koloid, mengandung sekitar 140 residu tirosin yang diperlukan untuk iodinasi. Peroksidase tiroid merupakan enzim yang berperan dalam iodinasitiroglobulin, membenam dalam membran vesikel sekresi dan terpapar dengan permukaan luminal sel tiroid saat proses eksositosis. Peroksidase tiroid ini teraktivasi selama eksositosis dan berfungsi mengoksidasi iodida menjadi iodine dalam koloid untuk selanjutnya ditransfer ke akseptor residu tirosiltiroglobulin. Fase endokrin dimulai dengan stimulasi TSH untuk proses endositosistiroglobulin yang teriodinasi dalam sel folikel. Pertama-tama droplet koloid diselubungi pseudopod apikal dan dimasukkan ke dalam vesikel yang mengandung koloid. Berbagai komponen sitoskeletal mengarahkan droplet koloid untuk bergabung dengan lisosom. Lisosomakan menghasilkan enzim lisosomal yang mampu mendegradasi iodotiroglobulin menjadi T3 (triiodotironin, bentuk aktif dari hormon tiroid), T4 (tiroksin) dan berbagai produk antara lainnya. Iodotirosin, asam amino dan gula kembali ke dalam sel, sedangkan hormon tiroid yang dihasilkan selanjutnya dilepaskan melalui bagian basal epitel folikel tiroid dan bergabung dengan serum carrier protein dalam pembuluh kapiler. $(11,12)$

T3 memiliki waktu paruh yang lebih pendek (18 jam) dan jumlahnya relatif lebih sedikit, tetapi efeknya lebih kuat. T4 memiliki waktu paruh selama 5 hingga 7 hari dan menjadi $90 \%$ dari keseluruhan hormon tiroid yang disekresikan. Hormon tiroid ini berfungsi meningkatkan kecepatan metabolik basal melalui aktifitas T3 dan sedikit T4 pada inti sel dengan berikatan pada reseptor hormon tiroid yang spesifik terhadap bagian DNA yang disebut dengan thyroid hormone-responsive element (TRE), yang selanjutnya dapat memicu transkripsi gen tertentu. ${ }^{(8,11)}$

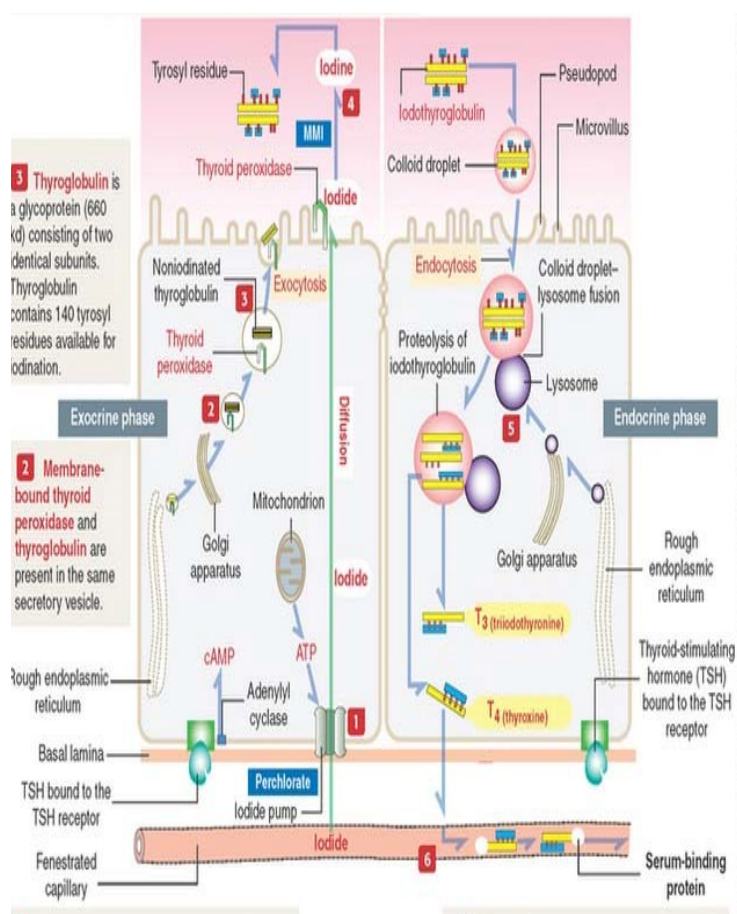

Gambar 3. Dua fase sintesis dan sekresi hormon tiroid yaitu fase eksokrin dan fase endokrin

(Gambar ini diambil dari Kierszenbaum (2007) Elsevier)

\section{Perkembangan Tiroid}

Perkembangan ukuran tiroid sangat tergantung pada berat badan, jenis kelamin, daerah geografis tempat tinggal, berbagai kondisi fisiologis (pubertas, kehamilan dan menopause), dan berbagai perubahan patologis (nodul, kondisi inflamasi, tumor). Perubahan patologis ini lebih sering terjadi pada area goiter endemik. Marine telah merumuskan estimasi rasio perbandingan berat kelenjar tiroid dengan berat badan yang diperkirakan tidak lebih dari 0,35 gram per kilogram berat badan. Tetapi Sigurjonsson menemukan bahwa rata-rata berat kelenjar tiroid sekitar 14 gram pada dewasa pria dan 11,6 gram pada dewasa wanita. ${ }^{[7}$ Penelitian eksperimental McCarrison pada hewan coba menunjukkan hewan coba dari area non goiter menunjukkan rasio konstan antara berat kelenjar tiroid dengan berat badan pada berbagai usia, namun hal ini tidak dijumpai pada hewan coba dari area endemik goiter karena adanya akumulasi koloid pada kelenjarnya. ${ }^{[8]}$ 
Ditemukan pula adanya rasio khusus berat kelenjar tiroid dengan berat badan pada masa pubertas yang dikenal sebagai "goiter fisiologis" yang juga dijumpai di daerah non endemik. Goiter fisiologis merupakan hipertrofiparenkim yang reversibel, hanya sementara dan bukan merupakan manifestasi goiter endemik. Di daerah endemik, rasio berat kelenjar tiroid sebelum dan sesudah pubertas tinggi secara tidak imbang dengan berat badan, pada periode ini jenis kelamin memainkan peranan penting. Olesen dan Taylor menemukan bahwa meskipun ukuran kelenjar pada laki-laki lebih kecil daripada perempuan, ukuran kelenjar meningkat sebelum pubertas dan mulai menurun setelahnya, sedangkan pada perempuan akan terus meningkat setelah pubertas dan menurun hanya setelah dewasa. ${ }^{[7,8]}$ Berat kelenjar tiroid di area goiter lebih besar secara bermakna dibandingkan area non goiter dalam berbagai variasi usia sesuai kurva Gambar 4.

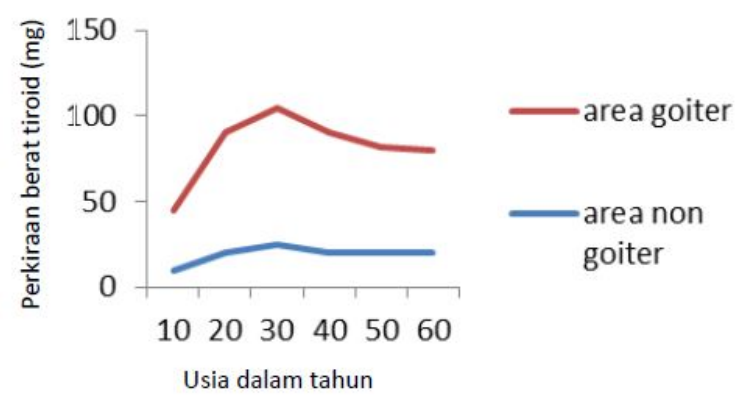

Gambar 4. Kurva beda rerata berat kelenjar tiroid di daerah goiter maupun non-goiter.

Suatu wilayah geografis disebut endemik jika lebih dari 10\% populasinya menunjukkan gejala klinis hipertrofi tiroid fokal maupun difus. Area goiter endemik umumnya ditandai dengan rendahnya kadar yodium tanah karena sangat rendahnya konsentrasi yodium pada air minum. Kelenjar akan beradaptasi dengan kondisi defisiensi yodium. Adaptasi ini juga dipengaruhi oleh berbagai faktor lain seperti kebutuhan metabolik atau penyerapan yodium dari makanan. Goiter yang disebabkan oleh hilangnya yodium berlebih melalui urin sangat jarang dan bukanlah tergolong endemik ${ }^{[13,14,15]}$.

\section{Epidemiologi Goiter}

Kasus goiter baik endemik maupun non endemik (sporadik) diyakini merupakan prekursor perkembangan kanker tiroid. Prevalensi goiter di seluruh dunia pada populasi umum sekitar $4-7 \%$, dan insiden keganasan terjadi pada $10 \%$ kasus tiroid goiter. Dilaporkan bahwa insiden karsinoma tiroid tercatat meningkat pada daerah goiter endemik seperti Kolumbia dan Austria serta daerah non endemik seperti Jerman. Peningkatan insiden karsinoma tiroid terkait goiter juga menjadi permasalahan di negara Asia Tenggara termasuk Indonesia. WHO mencatat sekitar 655 juta jiwa di dunia mengalami goiter dan $27 \%$ diantaranya berada di Asia Tenggara. ${ }^{[4]}$ Adapun perbandingan hasil studi epidemiologi karsinoma tiroid terkait goiter di beberapa Negara Asia Tenggara sesuai Tabel 1.

Serupa dengan wilayah lain di negaranegara Asia tenggara, beberapa wilayah di Indonesia tergolong daerah goiter endemik. Selain goiter yang bersifat endemik, sebagian kasus goiter yang terjadi di Indonesia bersifat non endemik. Hal ini sangat berbeda dengan insiden karsinoma tiroid di dunia barat yang lebih sering berkaitan dengan efek radiasi ${ }^{[16,17]}$

\section{Klasifikasi Goiter Secara Klinis \\ 1. Goiter yang bersifat Toksik}

Goiter toksik dapat dibedakan atas dua yaitu goiter difus toksik dan goiter noduler toksik. Istilah difus dan noduler lebih mengarah kepada perubahan bentuk anatomi dimana goiter difus bersifat meluas, teraba lebih kenyal tanpa batas yang jelas sedangkan goiter noduler menunjukkan benjolan yang secara klinis teraba jelas baik satu (single) maupun banyak (multinoduler). ${ }^{[18]}$

\section{Goiter yang bersifat Non Toksik}

Goiter non toksik sama halnya dengan goiter toksik dibagi menjadi goiter difus non toksik dan goiter noduler non toksik. Goiter non toksik disebabkan oleh kekurangan yodium yang kronik. Goiter 
ini disebut sebagai simple goitre, goiter endemik, atau goiter koloid yang sering ditemukan di daerah yang air minumya rendah yodium dan daerah dengan goitrogen yang menghambat sintesa hormon oleh zat kimia. Goiter noduler yang tidak disertai tanda-tanda hipertiroidisme dan hipotiroidisme disebut goiter nodulernon toksik. ${ }^{[18]}$

Tabel 1. Perbandingan studi epidemiologi karsinoma tiroid terkait goiter di beberapa Negara Asia Tenggara ${ }^{[4]}$

\begin{tabular}{|c|c|}
\hline Studi; tahun & Kesimpulan dan diskusi \\
\hline $\begin{array}{l}\text { Sarawak; } \\
\text { 2000-2004 }\end{array}$ & $\begin{array}{l}\text {-Insiden secara signifikan lebih } \\
\text { tinggi pada pria }(\mathrm{p}=0,01) \\
\text {-Prevalensi tertinggi pada rentang } \\
\text { usia } 21-40 \text { tahun } \\
\text {-Tipe histologistersering: KTP }\end{array}$ \\
\hline $\begin{array}{l}\text { Kelantan; } \\
\text { 1994-2004 }\end{array}$ & $\begin{array}{l}\cdot 28,1 \% \text { dari } 1.480 \text { lesi tiroid } \\
\text { merupakan lesi neoplastik } \\
\text {-Tersering adalah KTP }(76,6 \%) \\
\text { - Mayoritas kasus }(59,9 \%) \text { terjadi } \\
\text { dengan latar belakang } \\
\text { hiperplasianoduler } \\
\text {-Studi menunjukkan karsinoma } \\
\text { tiroid yang berkembang dari MNT } \\
\text { terbanyak pada area defisiensi } \\
\text { iodium }\end{array}$ \\
\hline $\begin{array}{l}\text { Perak; } \\
\text { 2004-2007 }\end{array}$ & $\begin{array}{l}\text {-Bukan merupakan area endemik, } \\
\text { sampel sedikit tetapi Karsinoma } \\
\text { tiroid lebih tinggi dari daerah lain } \\
(11 \%) \text { dan KTP }(57,5 \%) \\
\text {-Rentang usia } 21-60 \text { tahun, } \\
\text { tertinggi pada ras Malay, diikuti } \\
\text { India kemudian China. }\end{array}$ \\
\hline $\begin{array}{l}\text { Myanmar; } \\
\text { 1996-1998 }\end{array}$ & $\begin{array}{l}- \text { Kejadian karsinoma tiroid diantara } \\
\text { keseluruhan kasus lebih tinggi } \\
\text { secara signifikan; } p<0,0001 \\
\text {-Frekuensi secara signifikan lebih } \\
\text { tinggi pada pasien usia } 21-60 \\
\text { tahun; } p<0,008 \\
\text {-KTP dan adenoma folikuler secara } \\
\text { signifikan lebih tinggi dari tipe } \\
\text { lainnya; } p=0,003 \\
\text {-Peningkatan insiden tiap tahun; }\end{array}$ \\
\hline
\end{tabular}

Keterangan: KTP: Karsinoma Tiroid papiler MNT: MultipelNodul Tiroid

\section{Patogenesis Karsinoma Tiroid dengan Goiter sebagai Faktor Predisposisi}

Goiter merupakan proliferasi kelenjar tiroid yang dapat terkait kondisi eutiroid, hipo- maupun hipertiroid akibat penyakit primer pada tiroid maupun rangsangan sekunder oleh faktor hormonal maupun faktor lain. ${ }^{[19,20]} \mathrm{Di}$ Indonesia, beberapa wilayah masih tercatat sebagai daerah endemis goiter akibat rendahnya asupan iodium. Adapula kasus goiter dengan etiologi yang belum jelas diketahui, dikenal sebagai goiter sporadik diyakini berkaitan dengan faktor biologis intrinsik (prevalensi goiter lima hingga sepuluh kali lipat lebih sering terjadi pada wanita daripada laki-laki), goitrogen alami, merokok, defisiensi zinc atau selenium dan stres emosional. ${ }^{[19,21]}$

Goiter dapat menimbulkan hiperplasia yang bersifat difusa maupun noduler (nodul tunggal dan multipel) dan dipercaya mempengaruhi peningkatan insiden KTP. Analisis klonal telah dimanfaatkan dalam membedakan hiperplasia dengan neoplasia, dimana hiperplasia digolongkan sebagai proliferasi yang bersifat poliklonal sedangkan neoplasia merupakan proliferasi monoklonal dari sel yang mengalami transformasi genetik. Pada tiroid, ditemukan perubahan pola monoklonal pada kelompok nodul yang sebelumnya merupakan nodul hiperplastik. ${ }^{[22,23]}$ Mekanisme bagaimana perubahan poliklonal menjadi monoklonal ini merupakan interaksi antara faktor risiko goiter dan adanya predisposisi genetik yang selanjutnya menciptakan lingkungan mutagenik yang ditandai oleh peningkatan proliferasi sel disertai pembentukan radikal bebas yang memicu adanya mutasi somatiktirosit. Klonal tumor terbentuk jika defek genetik tidak dapat diperbaiki. Pada kondisi ini, mutasi merupakan pencetus proliferasi sel. Goiter meningkatkan risiko. ${ }^{[1,3,4]}$ karsinoma tiroid sebanyak dua setengah kali lipat. ${ }^{[19]}$ Data epidemiologis menunjukkan bahwa insiden karsinoma tiroid yang berkembang dari goiter berkisar antara 7,5\% hingga $13 \%$. . ${ }^{[6]}$ 

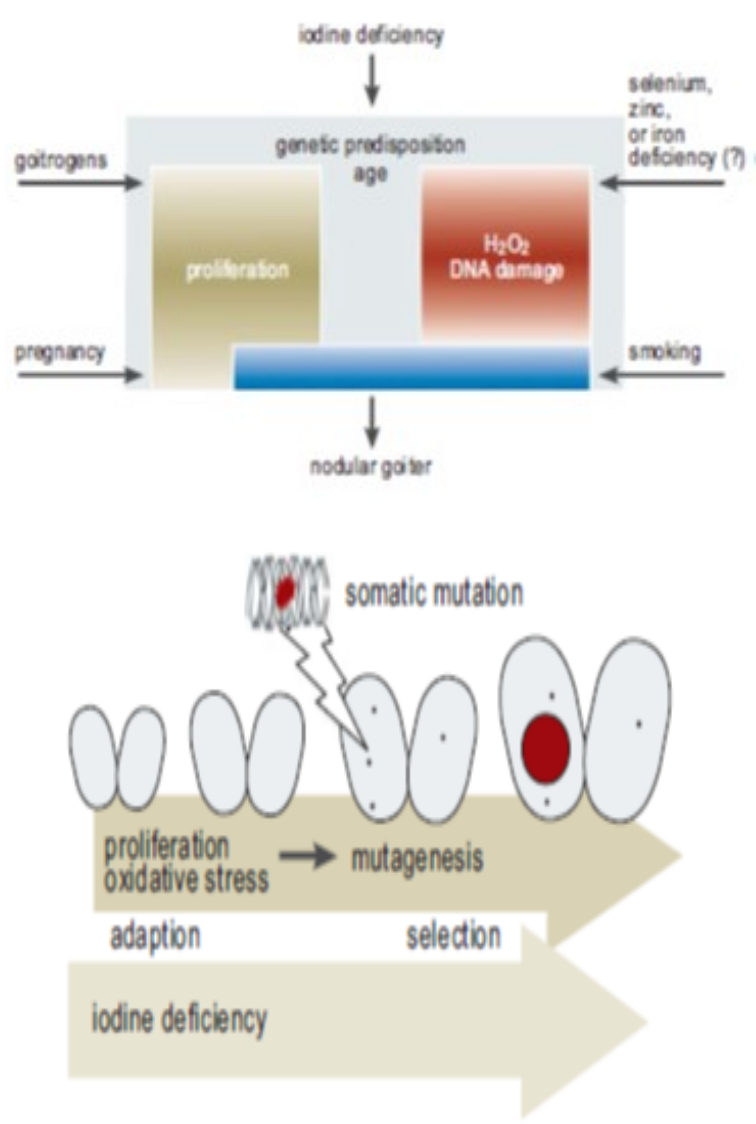

Gambar 5. Mekanisme nodul goiter sebagai faktor risiko $\mathrm{KTP}^{[2]}$

Insiden KTF lebih tinggi terjadi pada area goiter endemik dan berkaitan dengan rendahnya asupaniodium. Sedangkan insiden KTP lebih sering berkaitan dengan goiter sporadik pada area dengan asupaniodium yang cukup. Sebuah penelitian eksperimental pada hewan coba yang sebelumnya dengan asupaniodium rendah kemudian diberikan suplementasiiodium menunjukkan terjadinya perubahan morfologi folikuler menjadi papiler. Hal ini menunjukkan peranan kadariodium lebih penting dalam memodulasi morfologi tumor daripada inisiator pada karsinogenesis tiroid. Jika propilaksisiodium diberikan, maka terjadi penurunan rata-rata $\mathrm{TSH}$ (Thyroid Stimulating Hormone) serum dan peningkatan perbandingan rasio struktur papiler: folikuler. ${ }^{[1,24,25]}$ Iodium akan menghasilkan iodine radioaktif yang berkaitan dengan kerusakan rantai DNA melalui tata ulang RET-TRK.

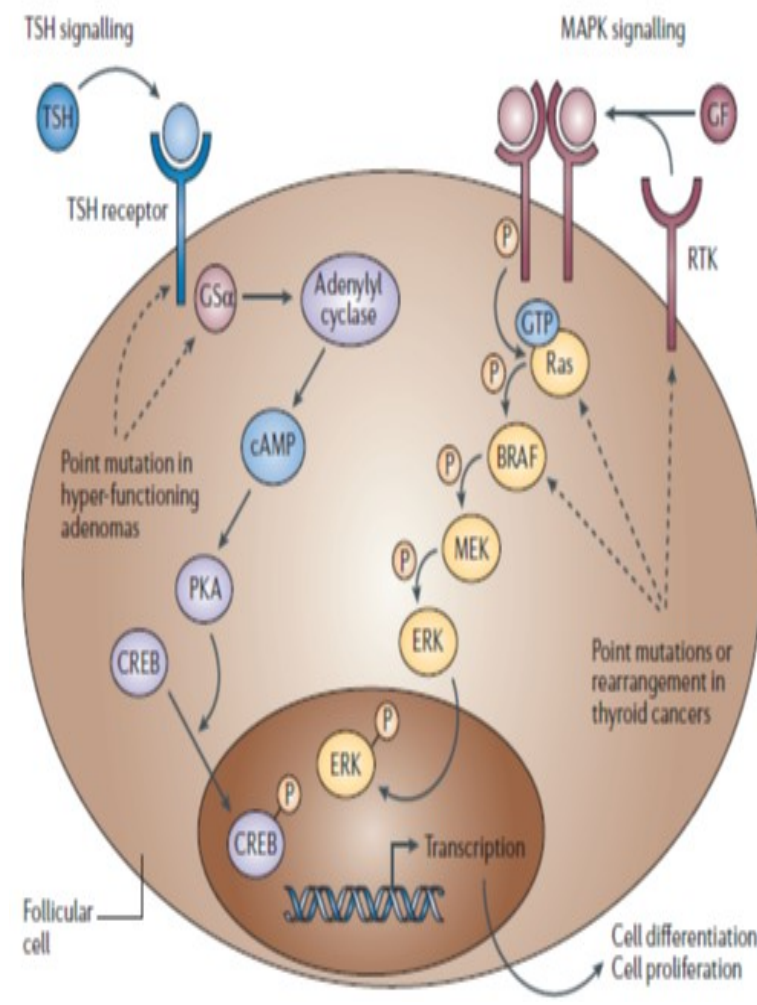

Gambar 6. Mekanisme molekuler yang mendasari karsinogenesis karsinoma tiroid (Gambar ini diambil dari Kondo, Ezzat dan Asa (2006) nature publishing group)

Selain itu peningkatan asupan iodium juga berkaitan dengan frekuensi mutasi $\mathrm{BRAF}_{\mathrm{V} 600 \mathrm{E}}$ dengan mekanisme yang belum diketahui dan baru dibuktikan melalui beberapa studi epidemiologi. ${ }^{[23,26]}$

\section{SIMPULAN}

Berdasarkan studi kepustakaan terdapat kaitan terjadinya karsinoma tiroid pada kasus goiter baik goiter toksik maupun non toksik dengan pembesaran difus maupun noduler. Aktivitas proliferatif tirosit menjadi acuan adanya perubahan neoplastik pada kasus goiter sehingga sangat penting pada hasil pemeriksaan histopatologidiberikan jawaban ada atau tidak adanya fokus proliferatif pada kasus goiter. Selanjutnya dapat dikembangkan studi analitik dalam menentukan kaitan kasus goiter dengan karsinoma tiroid. 


\section{DAFTAR PUSTAKA}

1. Kondo, T., Ezzat, S., Asa, S.L.Pathogenetic mechanisms in thyroid follicular-cell neoplasia. Nature Reviews, 2006; 6 (Suppl. 4): 292-306.

2. Führer, D., Bockisch, A., Schmid, K.W. 2012. Euthyroid Goiter With and Without Nodules-Diagnosis and Treatment. Medicine, 2012; 109 (Suppl 29-30): 506-516.

3. Fuhrer, D. Genetics of Benign and Malignant Tumours. Thyroid International, 2006; 2: 1-10.

4. Htwe, T.T. Thyroid malignancy among goitrous thyroid lesions: a review of hospital-based studies in Malaysia and Myanmar. Singapore Medical Journal; 2012; 53 (Suppl. 3): 159-163.

5. Dirjen Yanmed. 2008-2010. Kanker di Indonesia. Dirjen Yanmed Departemen Kesehatan RI.

6. Memon, W,.Khanzada, T.W.,Samad, A., Kumar, B. 2010. Incidence of thyroid carcinoma in multinodular goiters. Rawal Med J; 2010: 35.

7. Smet, D. Pathological Anatomy of Endemic Goitre. World Health Organization. Lyon: IARC Press.2010; p. 315-330.

8. Kieserbaum, A.L. Endocrine System. Histology and Cell Biology: An Introduction to Pathology. Mosby: Elsevier. 2007; p. 537-542.

9. Ershler, W.B., Longo, D.L. Aging and Cancer: Issues of Basic and Clinical Science. J Natl Cancer Inst, 2014; 89:1489-97

10. Frasca, F., Nucera, C., Pellegriti, G., Gangemi, P., Attard, M., Stella, M., Loda, M., Vella, V., Giordano, V.C., Trimarchi, R., Mazzon, E., Belfiore, A., Vigneri, E. BRAF(V600E) mutation and the biology of papillary thyroid cancer. Endocrine-Related Cancer, 2008; 15: 191-205.

11. Baloch, Z.W., Livolsi, V.A. Pathology of Thyroid and Parathyroid Disease. In: Stancey E. Mills, editors. Sternberg's
Diagnostic Surgical Pathology, 5th. Ed. Philadelphia: Wolters Kluwer Lippincott Williams and Wilkins. 2010; p. 500-503.

12. Chien, W., Koeffler P. Molecular Biology of Thyroid Cancer. Springer Endocrine Updates, 2012; 30: 35-43.

13. Knobel, M., Neto, G.M. Relevance of Iodine Intake as a Reputed Predisposing Factor of Thyroid Cancer. Arq Bras EndocrinolMetab; 2007; 5 (Suppl. 5): 701-712.

14. Chang, H.Y., Lin, J.D., Chou, S.C. Clinical presentations and outcomes of surgical treatment of follicular variant of the papillary thyroid carcinomas. Jpn J ClinOncol; 2006 (Suppl. 36): 688-93.

15. Boucek, J., Kastner, J., Skrivan, J., Grosso, E., Gibelli, B., Gaugliano, G., Betka, J. 2009. Occult Thyroid Carcinoma.

ActaOtorhinolaryngologicaItalica, 2009; 29:296-304.

16. Brito, J.P., Hay, D.I., Morris J.C. Low risk papillary thyroid cancer. British Medical Journal, 2014; 348: 1-8.

17. Cho, J.K., Kim, J.Y., Jeong, C.Y., Jung, E.J., Park, S.T., Jeong, S.H., Ju, Y.T., Lee, Y.J., Hong, S.C., Ha, W.S., Choi, S.K. Clinical features and prognostic factors in papillary thyroid microcarcinoma depends on age. Journal of the Korean Surgical Society, 2012; 82 (Suppl. 5): 281-7.

18. Kumar., Abas., Fausto., Aster. Neoplasm. In: Robbins Cotran Pathologic Basis of Desease Eight Edition. Kumar Vinay. Philadelphia: Saunders Elsevier. 2010; p. 62-70.

19. Cossu, A., Budroni, M., Paliogiannis, P., Palmieri, G., Scognamillo, F., Cesaraccio, R., Attene, F., Trignano, M., Tanda, F. Epidemiology of Thyroid Cancer in an Area of Epidemic Thyroid 
Goiter. Hindawi, 2013: 1-4.

20. DeLellis, R.A., Williams, E.D. Thyroid and Parathyroid Tumours: Introduction. In: DeLellis, R.A., Lioyd, R.V., Heitz, P.U., Eng, C., editors. World Health Organization Classification of Tumours, Pathology \& Genetics Tumours of Endocrine Organs. Lyon: IARC Press.2004; p. 51-6.

21. Ghossein, R. Update to the College of American Pathologists Reporting on Thyroid Carcinomas. Head and Neck Pathol Humana Press; 2009 (Suppl. 3): 86-93.

22. Gonzalez, R.G., Molina, R.B., CarreonBurciaga, R.G., Gastelum, M.G., Frechero, N.M., Rodriguez, S.S. Papillary Thyroid Carcinoma: Differential Diagnosis and Prognostic Values of Its Different Variants. International Scholarly Research Network ISRN Oncology, 2011: 1-9.
23. Pellegriti, G., Frasca, F., Regalbuto, C., Squatrito, S.,Vigneri, R.. Worldwide Increasing Incidence of Thyroid Cancer: Update on Epidemiology and Risk Factors. Hindawi, 2013; 1-7.

24. LiVolsi, V.A. 2011. Papillary thyroid carcinoma: an update.Modern Pathology. 2011; 24: 1-9.

25. Nikiforov, Y.E. Thyroid Tumors: Classification, Staging, and General Considerations. In: Hubbard J.G.H., Inabnet, W.B., Yau Lo, C., editors. Endocrine surgery. London: Springer. P. 2009; 108-112.

26. Viglietto, G., Marco, C.D. 2012. Molecular Biology of Thyroid Cancer. Springer Endocrine Updates 2012; 30: $35-43$. 